Shopping-Mall Shakespeare: Quartos, Folios, and Social Difference

Author(s): Leah S. Marcus

Source: The Huntington Library Quarterly, Vol. 58, No. 2 (1995), pp. 161-178

Published by: University of California Press

Stable URL: http://www.jstor.org/stable/3817819

Accessed: 16/11/2009 14:16

Your use of the JSTOR archive indicates your acceptance of JSTOR's Terms and Conditions of Use, available at http://www.jstor.org/page/info/about/policies/terms.jsp. JSTOR's Terms and Conditions of Use provides, in part, that unless you have obtained prior permission, you may not download an entire issue of a journal or multiple copies of articles, and you may use content in the JSTOR archive only for your personal, non-commercial use.

Please contact the publisher regarding any further use of this work. Publisher contact information may be obtained at http://www.jstor.org/action/showPublisher?publisherCode=ucal.

Each copy of any part of a JSTOR transmission must contain the same copyright notice that appears on the screen or printed page of such transmission.

JSTOR is a not-for-profit service that helps scholars, researchers, and students discover, use, and build upon a wide range of content in a trusted digital archive. We use information technology and tools to increase productivity and facilitate new forms of scholarship. For more information about JSTOR, please contact support@jstor.org. 


\section{Shopping-Mall Shakespeare: \\ Quartos, Folios, and Social Difference}

Leah S. Marcus

I

$\mathrm{n}$ his groundbreaking edition of the poetry of John Donne, published in 1912, Herbert J. C. Grierson took particular care to distinguish between the discipline of history and his own discipline of literary criticism. "Literary history," he asserted, "has for the historian a quite distinct interest from that which it possesses for the student and lover of literature." The historian may take "positive interest" in connecting "Donne's wit with the general disintegration of mediaeval thought" or in recognizing Machiavelli's influence on Elizabethan drama. But for the "lover of literature none of these facts has any positive interest whatsoever. Donne's wit attracts or repels him equally whatever be its source; Tamburlaine and lago lose none of their interest for us though we know nothing of Machiavelli." For Grierson, the literary text's historical setting and material embodiments were clearly separable from its essence-so many veils of "outworn fashions and conventions" that had to be cast off by literary scholars before a given work could be relished in its true nature. The literary scholar "studies history that he may discount it." 1

It is amusing, even astonishing, to reflect upon the ways in which our conceptions of the twin disciplines of literature and history have changed in the eighty years since Grierson's pronouncement. At the time he made it, English was a relatively new discipline, still not formally taught as such at some major universities, still in danger of being re-engulfed in the historical philology of the nineteenth century out of which it had only recently emerged. Now, eighty years later, the discipline of English has reversed Grierson's clear sense of disciplinary strengths and priorities. It is no longer the business of the literary scholar to

I would like to acknowledge the contributions of Kevin Sharpe, David Cressy, and other participants at the 1993 Huntington Library Conference "Culture, Politics, and Society in Elizabethan and Early Stuart England," at which this paper was originally delivered. Scattered material in the essay is reproduced with permission from Unediting the Renaissance: Shakespeare, Marlowe, Milton (London, 1996).

1. The Poems of John Donne, ed. Herbert J. C. Grierson (Oxford, 1912), 2:v-vi. 
uncover the "essential" work of literature beneath the veil of history. The very idea that there is such an unchanging essence to literature, as opposed to the untidy flux of history, has been discounted by literary scholars of the last decade who have dismantled what we now scornfully term essentialist views of literature in favor of a new paradigm that reinvests literature with all of the local contingencies surrounding its creation and reception. These days, we do not "study history that we may discount it," but that we may redefine the work of literature as always and intrinsically historically situated, radically dependent for its meaning on the matrix of institutions and ideologies within which it is placed at any given time.

Nevertheless, we literary scholars are arguably as devoted to certainties and absolutes as Grierson was-we simply look for them in disciplines apart from our own, especially in the social sciences. ${ }^{2}$ We look to historians to provide us with reliable models of the past so that we can break the literary work out of its spellbinding aura of inalterability and reinscribe it within one or many situations of cultural contingency that somehow feel more real to us than the appeals to "universal human nature" and "experience" that felt so real to Grierson.

The New Historicism is particularly noteworthy for its essentialization of historical contingencies through its use (or abuse) of the "initial anecdote"-a brief, striking historical narrative that begins an essay and serves as a "ground," almost in the musical sense of the term, upon which arabesques of interpretation and deconstruction are played in near infinite variation. But for most New Historicists, history is synchronic: the ground itself is posited as stable and reliable even though its signification may be perceived as multiple rather than single, and even though our sense of its meaning may alter-indeed is likely to do so-during the course of a given essay. Where Grierson turned to literature for a refuge from the vicissitudes of history, literary critics are now more inclined to use history as a stable jumping-off point into the vicissitudes of literature.

Historians of the early modern era frequently use literature in the same way that we literary scholars use the historical anecdote and historical data: as a device for confirming and anchoring meaning. Even historians who are strongly aware of the mediated nature of literary texts are prone to cite them as striking, concrete illustrations of an interpretation they are putting forth-a frozen image of the reality they want to posit. We each use the other discipline to confer a kind of

2. The context of the conference at which this paper was delivered led me to focus on the relations between literary study and history, as opposed to anthropology and sociology, although these two disciplines are as prominent in the field of literary studies as history is. 
truth value upon our own that we are not willing to grant our discipline within its own methodological terms. Indeed, that tendency may be one of the few clear disciplinary markers left within the larger field of early modern studies: if we trust literature, we must be historians; if we trust history, we must be literary critics.

Here I would like to concentrate on an interesting area in which the collaboration of the two disciplines is particularly rewarding, and in which they need to cooperate much more than they have-that is, the new field of textual studies that investigates the historically situated nature of textual production (whether manuscript or printed material) and textual alteration over time. As literary critics have done until very recently, historians of the early modern era have relied on the standard editions of literary works of the Elizabethan and Stuart era as though they offered transparent windows on the age, unmediated access to the minds and mores of the culture. Given the growth within the discipline of literature of a new textual studies-or, as I prefer to think of it, a "new philology," because in many ways we are reviving a nineteenth-century philological vision of the interpenetration of literature and history-that sense of transparency has become increasingly occluded. The new philology can be considered a branch of the new international movement studying the "history of the book." It takes a firmly revisionist stance toward the mainstream twentieth-century editorial tradition, investigating the ways in which the material texts of a work of literature have altered over time and reinvesting them with a historical contingency that Grierson-and most twentieth-century editors-have sought to lift them out of. For Grierson, history was to be studied in order to be discounted. We need historians to help us study differences among early versions of Shakespeare and Marlowe and Donne, so that we will not be tempted to discount the phenomenon of historical difference among variant early texts.

What I would like to do here is consider alternative early versions of canonical Renaissance texts that the editorial tradition has suppressed (and suppressed is not too strong a term). ${ }^{3}$ How can both literary scholars and historians cast off a set of editorial conventions that have caused us passively to receive our standard

3. I am by no means the first to take an interest in such matters; see, for example, Gary Taylor and Michael Warren, eds., The Division of the Kingdoms: Shakespeare's Two Versions of King Lear (Oxford, 1983); Random Cloud [Randall McLeod], “The Marriage of Good and Bad Quartos," Shakespeare Quarterly 33 (1952): 421-31; Steven Urkowitz, Shakespeare's Revision of King Lear (Princeton, N.J., 1980); and Arthur Marotti, Manuscript, Print, and the English Renaissance Lyric (Ithaca, N.Y., 1994). Among these proponents of the new philology, I am perhaps the one most interested in the historical and cultural interpretation of alternative texts. 
Renaissance authors already imprinted with eighteenth- and nineteenth-century tastes and cultural assumptions? I am less interested for the moment in offering answers than in opening up discussion about the meaning and significance of the textual instability that is much more the norm for literature of the early modern era than the exception. ${ }^{4}$

Until fairly recently, there has been significant agreement about some formal features of one of our favorite cultural (and culture-confirming) rituals: attendance at a performance of Shakespeare. The performance text can certainly be cut (and usually is), but it needs to preserve a certain length and magnitude. Even Midsummer Night's Dream cannot be successfully performed in forty-five minutes; too much will be lost. Similarly, we tolerate a degree of experimentation and modernization, so long as Shakespeare's elevation of language and dramatic action is not altogether effaced. All but one of his plays focus on the actions of persons of "quality," and we associate that quality with Shakespeare himself, whose very name ("Shake-speare") connotes martial valor, even though the man was of relatively humble origin. Despite a significant current of Bard-bashing in recent years, Shakespeare is enshrined as one of our major cultural icons: we have come to expect a certain decorum in connection with his name and his poetry, an experience of cultural enrichment and elevation.

But what are we to do if we encounter printed Shakespearean texts from the late sixteenth and early seventeenth centuries that are too short to be decently "Shakespeare," or too "low" and "popular" to be properly elevating? Even to use the term popular is to beg a number of questions I would like to examine. These "low" Shakespearean texts have, for most of our century, been called "bad" quartos. They are early quarto versions of some of the plays that twentiethcentury editors have dismissed-nay, suppressed-as corrupt, contaminated copies without any intrinsic merit.

In Texas, where I live and teach, there is an annual drama contest in which high schools vie for a state title by performing forty-five-minute versions of major plays. Often they perform Shakespeare plays that, if the cutting is skillfully made, survive the diminution quite nicely. The movement toward "short Shakespeare" is not exclusively American. There is at least one British company currently performing short versions of Shakespeare in casual settings that do not require the elaborate ritual of full-dress and full-length performance. On the American cable

4. Two of the examples that follow-Hamlet and The Merry Wives of Windsor-are treated in greater detail in Unediting the Renaissance. 
station $\mathrm{HBO}$, a series of cartoon versions of Shakespeare, including Hamlet, has been presented recently. Some of those who have seen these cartoons have pronounced them a success, although all such condensations suffer the social and intellectual stigma of having defaced one of our major cultural monuments. But "defaced" versions of the plays_- "Shopping-Mall Shakespeare," we might say, tying them to "low" or at least tainted aspects of modern American culturehave in fact long existed, although they have not been acknowledged as Shakespeare by the editorial tradition

It now appears quite likely that the "bad" quartos of Shakespeare-offering more streamlined versions of the plots, many fewer words, and often different patterns of action-may be, like such modern performances, designed for performance on tour, in guildhalls and inns rather than in established theaters. These versions may have been altered by the Bard himself rather than the meddling outsiders posited by advocates of the "contamination" theory of the bad quartos. Although many scholars working on these quartos would like to posit them as always reliably Shakespearean, another possibility is that the bad quartos offer source plays that were then rewritten by Shakespeare, perhaps in collaboration with others. But even if, as the dominant twentieth-century theory would have it, the bad quartos are Shakespeare plays cut down and rewritten by others-lesser members of the company or even its hired men-they should still be of strong interest to historians and historically minded literary critics as registers of cultural difference. Many questions about the dating of Shakespeare's plays have been reopened with the revaluation of the bad quartos. Here I consider textual variations that the new philology is beginning to reconceptualize as Jacobean or very late Elizabethan overlays upon earlier Elizabethan materials.

We might start out by considering the variation in titles between the early quarto version of Shakespeare's Henry VI part 2 and the 1623 First Folio version of the play. Through much of the nineteenth century, the dominant critical opinion was that the quarto version was a source play for Shakespeare. But that theory allowed too little scope for twentieth-century worship of the Bard's creativity and originality. Through much of this century, the early quarto has been considered later than the genuine play-a corrupt copy or memorial reconstruction of Shakespeare's original, which was assumed to resemble the folio version much more than it did the quarto. Now, the bad quarto is coming to be regarded as pretty "good," and certainly interesting-as perhaps Shakespeare's early version of the play, with the folio version representing authorial revision. 
In the case of Henry VI, we need to ask ourselves how much of the standard twentieth-century editorial conviction that the quarto is corrupt may have come from the disorderly title of the play in its earliest, quarto publication. Standard twentieth-century editions have established strict boundaries between the 1594 quarto, The First part of the Contention betwixt the two famous Houses of Yorke and Lancaster, with the death of the good Duke Humphrey, etc., and the 1623 folio play, The second Part of Henry the Sixt, with the death of the Good Duke Humfrey. Even if the contents of the two versions of Henry VI part 2 were identical, in what ways would the marked change in title alter a theatrical or reading audience's probable perception of the two plays?5 With a name emphasizing the dynamic of civil war and a struggle between two warring houses, The Contention arouses rather different expectations than does a Henry the Sixt named after the monarch reigning during the action of the play. The Contention appeared in a small, seemingly throwaway quarto format; Henry the Sixt was offered readers in a large, impressive folio volume as part of a series of history plays arranged in proper dynastic order, all named after monarchs, and all offering a clear locus for authority through their very titles.

In this instance, it may have been the compilers of the First Folio-rather than Shakespeare himself-who were responsible for the changed titles and the greater sense of elevation and decorum in the folio version. We will probably never know who carried out the alterations. But the shift in title goes along with a series of subtle, pervasive differences between the texts themselves. In the Jack Cade episodes, for example, the rebel Cade has an element of sturdy, brutal autonomy in the quarto version; he is more clearly a buffoon - an ape of his betters-in the folio. The rebels are more sympathetically portrayed in the quarto, humanized through realistic touches not included in the folio version. They have their own culture, not just a debased imitation of chivalric culture. According to a stage direction in the quarto version, the rebels carry "long staues"; in the corresponding folio passage, they instead make swords out of laths. ${ }^{6}$ Those who have joined

5. For pioneering work on quarto/folio differences, see Steven Urkowitz, "Five Women Eleven Ways: Changing Images of Shakespearean Characters in the Earliest Texts," in Werner Habicht, D. J. Palmer, and Roger Pringle, eds., Images of Shakespeare: Proceedings of the Third Congress of the International Shakespeare Association, 1986 (Newark, Del., 1988), 292-304; Barbara Hodgdon, The End Crowns All: Closure and Contradiction in Shakeskpeare's History (Princeton, N.J., 1991); and Phyllis Rackin, Stages of History: Shakespeare's English Chronicles (Ithaca, N.Y., 1990), 55-56n. My own speculations are also indebted to Craig Bernthal's paper on the Contention, presented at the Shakespeare Association of America in 1989. See also Kathleen Irace's Reforming the "Bad" Quartos: Performance and Provenance of Six Shakespearean First Editions (Newark, Del., 1994). 
the rebellion include in the quarto version "Dicke the Butcher, and Robin the Sadler, and Will that came a wooing to our Nan last Sunday, and Harry and Tom, and Gregory that should haue your Parnill" (p. 65 [F3r]). In the folio the names are merely listed, with demeaning puns on each (TLN 2340-48). The nobles in Henry the Sixt part 2 consistently use pejorative epithets for the rebels and for the lower classes generally: these reinforce the feeling that the lower classes are not seen as a distinct social group in the folio version of the play but chiefly perceived through the eyes of their betters and in relation, or reaction, to them. In the quarto Contention, Cade and his followers articulate vague desires for liberty and social leveling; but in the folio Henry the Sixt part 2, the rebel is portrayed much more specifically as the enemy of established institutions —of the "Comomonwealth" and the "King's Council," of magistrates, lawyers, and those who can write "Court hand."

In both versions of the play, Cade and his followers execute Lord Saye not only for losing Normandy but also for establishing paper mills, encouraging printing and literacy, and establishing justices of the peace in every shire. But in the quarto, there is no internal regulating mechanism to influence the audience's perception of Cade's (to us) heinous and barbaric act. The response of any segment of the audience to Cade's program would depend entirely on their attitudes toward the institutions he and his followers despise: the unruly apprentices who frequented the theater might have heartily sympathized with Cade's violence against the slavery of enforced literacy and the tyranny of petty magistrates. In the folio, the rebels' accusations are similar but Lord Saye is allowed polished speeches in defense of justice, learning, and civility that cause even Cade himself to express remorse at Saye's execution before putting him to death anyway. If rebel Cade can sympathize with Saye's defense of literacy and order, then audience sympathy may be won over, superseding social divisions not addressed in the quarto version of the episode.

We need to ask ourselves whether the folio version has appeared to editors more quintessentially "Shakespearean" than the quarto because it is more clearly weighted toward a vision of established authority than the quarto. In the quarto, mob violence has an odd legitimacy; in the folio, it is carnivalized and reduced, brought within broader institutional patterns that register it as aberrant.

6. See Shakespeare's Plays in Quarto: A Facsimile Edition of Copies Primarily from the Henry E. Huntington Library, ed. Michael J. B. Allen and Kenneth Muir (Berkeley, Calif., and London, 1981), 65 (F3r); and The Norton Facsimile: The First Folio of Shakespeare, ed. Charlton Hinman (London and New York, 1968), Through Line Number 2320. References to these two editions, the latter abbreviated "TLN," are given subsequently in the text. 
Certainly, if we are interested in discussing Henry VI Part 2's mapping out of society-particularly in terms of rebellion and its social contexts-we would do well to distinguish quarto clearly from folio and ask ourselves hard questions about the differences between them.

Merry Wives of Windsor is another play with a bad quarto lurking in its shadows. Whereas The Contention has at times achieved the status of source play for Henry the Sixt part 2, the 1602 quarto A Most pleasaunt and excellent conceited Comedie, of Syr Iohn Falstaffe, and the merrie Wiues of Windsor has been generally excoriated as an unusually bad quarto-a late and non-Shakespearean corruption of the "true" text. It is indeed quite different from the folio version-it is considerably shorter, and its action is differently located. The 1623 folio version of Merry Wives has many topical and topographical references to Windsor town and castle, to the Chapel of St. George and the Order of the Garter, and to the Court sometimes resident at Windsor; in nearly every place where the folio specifies a Windsor locale, the quarto has a more generalized location that could easily be London rather than Windsor. Falstaff's great buck basket is carried "among the Whitsters in Dotchet Mead" in the folio (TLN 1363-64), merely "to the Launderers" in the quarto (p. 565 [D4r]). The characters run through country towns in the folio version, out of town into the fields in the quarto version. Characters in the folio frequently offer remarks anchored in their locale: "as any is in Windsor," "for ye wealth of Windsor castle" (TLN 866, 1543). This trick of language does not exist in the quarto version. In nearly every case where the folio refers to some feature of rural life in Windsor, enlivened by the presence of the court, the quarto creates a more identifiably urban equivalent, but without any mention of the court. Here I will cite only the most obvious instances. Instead of the folio's fairy visits to "Windsor-chimnies" and the castle-which must be kept clean since "Our radiant Queene, hates Sluts and Sluttery"- the quarto has Puck sending Peane to the "countrie houses" and Pead dispatched to a less obviously rural and Windsor setting:

go you \& see where Brokers sleep,

And Foxe-eyed Seriants with their mase,

Goe laie the Proctors in the street,

And pinch the lowsie Seriants face:

(P. 575-76 [G2v]) 
Of course, the folio's long, elaborate blessing of the castle itself and St. George's Chapel does not exist in the quarto:

About, about:

Search Windsor Castle (Elues) within, and out. Strew good lucke (Ouphes) on euery sacred roome, That it may stand till the perpetuall doome, In state as wholsome, as in state 'tis fit, Worthy the Owner, and the Owner it. The seuerall Chaires of Order, looke you scowre With iuyce of Balme; and euery precious flowre, Each faire Instalment, Coate, and seu'rall Crest, With Loyall Blazon, euermore be blest. And Nightly-meadow-Fairies, looke you sing Like to the Garters-Compasse, in a ring, Th'expressure that it beares: Greene let it be, More fertile-fresh then all the Field to see: And, Hony Soit Qui Mal-y-Pence, write In Emrold-tuffes, Flowres purple, blew, and white, Like Saphire-pearle, and rich embroiderie, Buckled below fair Knight-hoods bending knee; Fairies vse Flowres for their characterie.

(TLN 2537-55)

The folio version of Merry Wives is a comedy of small town and rural life, steeped in rustic customs and topography but also imbued with the presence of the royal court and the ritual of the Order of the Garter, whose symbols are written on the very landscape of the Windsor countryside by the "characterie" of the fairies. The quarto version, in which such rituals are entirely absent, is "lower," more urban-closer to the pattern of city or "citizen" comedy. 7

The quarto version, even though it may, as its title page asserts, have been performed before the queen, seems more oriented toward a middling sort of urban public; the folio, toward the court itself. The quarto is more sentimentalizing of family relationships: Anne and Fenton's union is a love match predating the play's action. We never find out how much Anne is "worth" in money; and it is clear that Fenton, although initially attracted to her, as he admits, for her wealth, remains attached to her out of love. In the folio, the match is just being

7. Pieces of this discussion have appeared in Shakespeare Quarterly 42 (1991): 168-78, and are reproduced by permission of its editor, Barbara Mowat. 
negotiated as the play opens. It is made explicit that Anne is worth $£ 700$ plus the inheritance expected from her father, and Fenton is distinctly more mercenary throughout, less convincingly in love with Anne apart from her money.

In the folio version, significantly, Fenton is of the court-identified as part of the disorderly retinue surrounding Prince Hal (later King Henry V). In the quarto, Fenton is of higher status than the rest of the characters but carries no particular courtly associations. In the folio, unlike the quarto, his union with Anne fits the stereotype of the impecunious courtier who marries downward to replenish his wasted revenue. The quarto's sentimental benevolence extends to other characters like Ford and even to Falstaff himself: in the quarto text the fat knight, once properly reformed, is forgiven his debt of $£ 20$ to Ford; in the folio he is expected to pay up. The quarto ends in an explicit reconciliation between Anne and her parents and the beginnings of a jolly wedding feast. The folio is terser, less celebratory: Anne is never explicitly reconciled with both of her parents, and it is never entirely clear that her father has forgiven her for marrying against his wishes.

One way of accounting for the differences between quarto and folio versions of Merry Wives would be to posit authorial revision for diverse audiences, either for different kinds of audiences during the same general time period, or perhaps to meet evolving tastes as theatrical audiences lost their appetite for sentimental comedy after the 1590s. Certainly both texts show signs of revision; neither is the "original." The quarto seems to articulate a "lower" pattern of expectations about family life than does the folio, and we might argue that the more romanticized version of Anne and Fenton's relationship would have appealed to an urban middle-class audience whereas the folio's more skeptical and mercenary portrayal of middle-class mores might have aimed at a "higher" audience more closely identified with the court.

Such, at least, is the analysis of differences between quarto and folio we might produce if we trusted some of the standard paradigms about "middle-class taste" that literary critics have borrowed from social historians, and not necessarily the best or most recent work of social historians. But to assert such a bald homology between social class and taste is to beg a number of questions: Did audiences like to see their own assumptions mirrored in plays they saw or read, or did they prefer being challenged by difference, by the subtle voyeurism of looking into lives at some cultural distance from their own? Was there enough uniformity in terms of attitudes for different social groups to be reliably identified on the basis of their beliefs about the court, money, or marriage? The standard editions of Merry Wives are of no use to us in the pursuit of answers to such questions because they conflate the two texts and intermingle patterns that are relatively distinct in quarto and folio. 
There is a similar, if less obvious, pattern of differences between the so-called first and second quartos of Romeo and Juliet. The first (Q1), An Excellent conceited Tragedie Of Romeo and Iuliet (1597), has been labeled bad and is considerably shorter than the second, good quarto (Q2), The Most Excellent and lamentable Tragedie, of Romeo and Iuliet (1599). The second quarto is the usual copy-text for modern editions of the play, and it was evidently used as copy for the 1623 folio version. In Q1, there are fewer long, flowery speeches in the mode of courtly compliment than there are in Q2; many exchanges between Romeo and Juliet are drastically shorter. Were the more rarified bits systematically eliminated by a nonShakespearean reviser-which would mean Q2 preceded Q1, as the bad quarto theory argues - or were they not yet part of the play at the time Q1 was written, which would make Q1 the earlier version after all?

The first quarto is a somewhat sunnier play than the second, as Urkowitz has noted. ${ }^{8}$ In Friar Lawrence's interviews with the two young lovers, for example, Q2 includes numerous foreshadowings of the ultimate fate of the pair that do not exist in Q1. The friar refers to earth's "burying graue" in his speech introducing the first conference with Romeo (p. 172 [D4v]). In their second conference, just before the arrival of Juliet, almost every speech in Q2 offers a hint of doom that is absent or more muted in Q1. The initial exchange in Q1 reads:

Rom: Now Father Laurence, in thy holy grant

Consists the good of me and Iuliet.

Fr: Without more words I will doo all I may,

To make you happie if in me it lye.

$$
\text { (P. } 135[\mathrm{E} 4 \mathrm{r}])
$$

The second quarto version of the initial exchange is tenser, darker with portent:

Fri. So smile the heauens vpon this holy act,

That after houres, with sorrow chide vs not.

$R o$. Amen, amen, but come what sorrow can,

It cannot counteruaile the exchange of ioy

(P. $177[\mathrm{~F} 1 \mathrm{v}])$

8. I am indebted to Urkowitz's paper, presented at the 1991 Shakespeare Association Meeting, "'Do me the kindnes to looke vpon this' and 'Heere, read, read': An Invitation to the Pleasures of Textual/Sexual $\mathrm{Di}(\mathrm{Per})$ versity." Since writing my own analysis of quarto/folio differences in Romeo and Juliet, I have encountered two studies complementary to my own: Linda Anderson's "Much upon these years': Evidence of Revision in Q2 Romeo and Juliet (with Reference to Q1)," and Jay L. Halio's "Handy Dandy: Q1/Q2 Romeo and Juliet," both presented at the Shakespeare Association of America's Text Seminar in April 1994. 
A few lines later, the friar in Q2 offers a speech of caution that does not exist in Q1:

Fri. These violent delights haue violent endes, And in their triumph die like fier and powder:

Which as they kisse consume. The sweetest honey

Is loathsome in his owne deliciousnesse,

And in the taste confoundes the appetite.

Therefore loue moderately, long loue doth so,

Too swift arriues, as tardie as too slowe.

$$
\text { (P. } 177[\mathrm{~F} 2 \mathrm{r}])
$$

Here and throughout the rest of the scene, as elsewhere in Q2, there is a sense of overhastiness and overshadowing doom about the lovers' passion that is much less evident in Q1. To similar effect, the chorus in Q2 is more frequently present and more pessimistic about the lovers' chances for happiness. In Q1, Romeo and Juliet die as a result of several unfortunate accidents of miscommunication, but in Q2 there is a relentless, overbearing fate that lowers upon their passion-in part, perhaps, because of its illicit and unauthorized nature as emphasized in that version.

Andrew Gurr has reminded us of the pervasiveness of marriage without parental consent as a subject for late Elizabethan and early Jacobean drama, and he has further suggested that Shakespeare's company may have been particularly associated with a new current of social opinion that favored the love match rather than arranged marriage. ${ }^{9}$ But the two versions of Romeo and Juliet themselves differ over the degree to which marriage without parental consent is viewed as unnatural and destructive, with Q1-like quarto Merry Wives-adopting a pattern that looks more sentimental (perhaps more "middle class") toward the lovers, and Q2-like folio Merry Wives-articulating an attitude that is more dynastic and aristocratic in its condemnation of marriage outside the control of family and friends.

In addition, the second quarto of Romeo and Juliet paints a much clearer picture of the social consequences of the lovers' rash act than does the first. Indeed, in Q1 it is far from clear that the death of the young lovers has brought peace to Verona. In Q2 the chorus states at the beginning of the play that Romeo and Juliet "with their death burie their Parents strife" and that "nought" but the deaths of the children could remove the "Parents rage," so that the sacrifice of the chil-

9. Andrew Gurr, "Intertextuality at Windsor," Shakespeare Quarterly 38 (1987): 189-200; see also Roslyn L. Knutson's “Rejoinder” and Gurr's reply, Shakespare Quarterly 39 (1988): 391-98. 
dren becomes essential for the restoration of social order (p. 157 [A2r]). The prince in Q2 expresses a similar sentiment at the end of the play. All of these lines about the larger social consequences of the love match are conspicuously absent from the corresponding passages in Q1. Indeed, in that version, the balance of moral obloquy falls more clearly on the feuding parents. But for their enmity, the two lovers could have married publicly, joyously, and without dire consequence.

What has happened between the two versions of the play? Has Shakespeare - who may himself have married against his parents' wishes-changed his mind on the subject? Is a different audience being addressed? Is the play being altered to accord with changing social norms on the subject of arranged marriage? Did late Elizabethan and early Stuart culture in fact witness a clear enough pattern of change that we can use it to establish which Romeo and Juliet came earlier?

Hamlet represents a yet more complicated textual situation, since it exists not in two distinct early versions but in three. The first quarto, The Tragicall Historie of Hamlet Prince of Denmarke (1603), is the one that has been condemned for reasons that will by now appear familiar to us. It is shorter than the others, often less elevated in its language, and much more direct in its action. The second quarto, the "good" one, is the text most often used as the basis for modern editions. Dated 1604 in some copies and 1605 in others, it bears the same title as the bad quarto, but while the 1603 quarto repeats the title page characterization of the play as "Tragicall Historie" in its head title (the inside title at the top of the text proper), the 1604 quarto head title elevates the play to a "Tragedie." In addition, the second quarto advertises on its title page that the play is "newly imprinted and enlarged to almost as much againe as it was, according to the true and perfect Coppie." Indeed, the second quarto is nearly twice the length of the first, and the claim on the title page links the authority of this version to its length. But the folio version (1623) is yet a third contender for textual authority, more closely resembling the bad quarto in some matters than it does the good quarto, agreeing with the good quarto in a number of particulars-but also including language and speeches that exist in neither quarto version.

Yet again, we need to examine each version of Hamlet separately-on its own terms-instead of rushing to conflate the three together, as modern editions of the play invariably do. Such an examination is obviously much too broad a task for the present brief survey. What I will consider here is a very small piece of the whole picture-the different handling of Hamlet's advice to the players in the three versions of the play. Again, as in the case of The Contention and Henry the Sixt part 2, we can perceive a pattern of gradually increased elevation and distance 
between the protagonist Hamlet and "low" elements of the play, from the first quarto to the second and to the folio version.

In the 1603 quarto, Hamlet offers a brief speech of advice to the players:

There be fellowes that I haue seene play,

And heard others commend them, and that highly too,

That hauing neither the gate of Christian, Pagan,

Nor Turke, haue so strutted and bellowed,

That you would a thought, some of Natures journeymen

Had made men, and not made them well,

They imitated humanitie, so abhominable:

Take heede, auoyde it.

The player responds, "I warrant you my Lord," and Hamlet continues with a specific description of the behavior of the clowns. As is frequently the case with bad quartos (and sometimes with good quartos as well), these speeches are prose erroneously printed out as poetry:

And doe you heare? let not your Clowne speake

More then is set downe, there be of them I can tell you

That will laugh themselues, to set on some

Quantitie of barren spectators to laugh with them,

Albeit there is some necessary point in the Play

Then to be observed; $\mathrm{O}$ t' is vile, and shewes

A pitifull ambition in the foole that vseth it.

And then you haue some agen, that keepes one sute

Of ieasts, as a man is knowne by one sute of

Apparell, and Gentlemen quotes his ieasts downe

In their tables, before they come to the play, as thus:

Cannot you stay till I eate my porrige? and, you owe me

A quarters wages; and, my coate wants a cullison:

And, your beere is sowre: and, blabbering with his lips,

And thus keeping in his cinkapase of ieasts,

When, God knows, the warme Clowne cannot make a iest

Vnlesse by chance, as the blinde man catcheth a hare:

Maisters tell him of it.

(Pp. 597-98 [F2])

In this version, Hamlet lingers over the poorly endowed clown's resort to stock lines, said to draw a laugh whatever the theatrical context because they have been anticipated by members of the audience-who have even gone so far as to write 
them down. Delivery of this speech would require Hamlet to mimic the standard jokes and perhaps stimulate an audience response quite similar to that aimed at by the clowns. The speech affords a concrete glimpse of actor-audience reaction in the popular theater, but this perspective is absent in the second quarto version of the repartee, where Hamlet offers instead a more sophisticated rationale for playing - his famous speech about suiting the action to the word, the word to the action; about not overstepping the modesty of nature but holding the mirror up to it, "to shew vertue her feature; scorne her owne Image, and the very age and body of the time his forme and pressure." He continues,

Now this ouer-done, or come tardie off, though it makes the vnskilfull laugh, cannot but make the iudicious greeue the censure of which one, must in your allowance ore-weigh a whole Theater of others. $O$ there be Players that I haue seene play, and heard others praysd, and that highly, not to speake it prophanely, that neither hauing th'accent of Christians, nor the gate of Christian, Pagan, nor man, haue so strutted $\&$ bellowed, that I haue thought some of Natures Iornimen had made men, and not made them well, they imitated humanitie so abhominably. (P. 636 [G3v-G4r])

We note that in this version, Hamlet has divided the audience between the "low" and the judicious-one of the latter is to be preferred over a whole house of the former. The player answers with a little more amplitude than in the first quarto version, "I hope we haue reform'd that indifferently with vs." Hamlet continues,

$\mathrm{O}$ reforme it altogether, and let those that play your clownes speake no more then is set downe for them, for there be of them that wil themselues laugh, to set on some quantitie of barraine spectators to laugh to, though in the meane time, some necessary question of the play be then to be considered, that's villanous, and shewes a most pittifull ambition in the foole that vses it: goe make you readie. (P. 636 [G4r])

The first quarto's vignette immersing us temporarily in the slapstick ethos of the popular stage is absent here, as the elevated talk about holding the mirror up to nature is absent from quarto one. The image Hamlet projects of the theater is noticeably more refined in the good than in the bad quarto. Furthermore, he insists on the the text's authority in the face of improvising clowns who were wont to say more than was "set downe for them" and to distract the audience's attention from "some necessary question of the play." And he has more strongly 
disavowed that segment of the audience incapable of the virtue and judgment that the theater teaches.

The folio version of the repartee is close to the second quarto version, with minor but interesting differences. For example, where the first quarto has "gate of Christian, Pagan, or Turke," and the second quarto "Christian, Pagan, nor man," the folio has "Christian, pagan, or Norman"-suggesting that the second quarto's "man" may be a printer's error, the "Nor" before the hyphen left out. But far more interesting in the folio version are the speeches about the contemporary status of the players, which precede Hamlet's advice. In the first quarto, before the players arrive, Guilderstone (Guildenstern in the more familiar versions of the play) advises Hamlet that the players are traveling because the "principall publike audience that / Came to them, are turned to priuate playes, / And to the humours of children." In the second quarto, the speech is similar but the players are slightly more elevated. Hamlet queries, "Doe they hold the same estimasion they did when I was in the City; are they so followed." Rosencrantz answers simply, "No indeede are they not," with no mention of the children's companies who have demeaningly eclipsed the adult players. The folio version of this passage (the one to which we are accustomed in standard texts of the play) is greatly expanded, and it forges, through topical specificity, an explicit link between Shakespeare's company performing the play of Hamlet and the players of Elsinore. We get much more information about the children's companies, as well as much fuller analysis of the basis for their appeal. Hamlet queries, "doe they [the adult players] grow rusty?" and Rosencrantz answers, "Nay, their indeauour keepes in the wonted pace; But there is Sir an ayrie of Children, little Yases, that crye out on the top of question; and are most tyrannically clap't for't: these are now the fashion, and so be-ratled the common Stages (so they call them) that many wearing Rapiers, are affraide of Goose-quils, and dare scarse come thither." To which, Hamlet:

What are they Children? Who maintains 'em? How are they escoted? Will they pursue the Quality no longer then they can sing? Will they not say afterwards if they should grow themselues to common Players (as it is like most if their meanes are noe better) their Writers do them wrong, to make them exclaim against their owne Succession. (TLN 1384-98)

In this version, there is an overlay of status anxiety in the portrayal of the plight of the players. Hamlet is incredulous that the boy companies have achieved the degree of prominence that they have, and he indirectly becomes a spokesman 
for the men's companies-indeed, for Shakespeare's own company. Hamlet's speeches-particularly when this segment of the action is combined with his analysis of the purpose of playing later on-subtly define the so-called common players apart from the status of menials or children and confer upon them the much higher function of mirroring humanity to itself in all of its vices and virtues. It is possible that the "little eyases" speech at one time existed in the second quarto as well but was stricken from that text as the subject lost topical interest. But each version of Hamlet's encounter with the players in the texts as we have them elevates the status of the theater as an institution by a notch or two (or perhaps argues for its elevation in relation to threats of one kind or another) and also elevates the actual company performing the play. Hamlet's comments about the players move them increasingly away from a popular image of the theater and toward a more refined and cultivated vision of it. Small wonder that our standard texts use the folio version, with its account of the status of the company: it is the one that accords most closely with our traditional exalted image of Shakespeare and our notion of the elegance and sophistication of the Shakespearean theater.

We have not solved the conundrum of which came first in terms of Shakespeare's creativity-good quartos, bad quartos, or folio text. But I have tried to suggest that a fairly consistent pattern corresponding to social differences emerges when the so-called bad and good texts are compared in systematic fashion in the order of their publication. The pattern may not hold for all divergent early texts, ${ }^{10}$ but it is evident and uniform enough to stimulate new investigation into the provenance, dating, and implied audiences of variant versions of Shakespeare, and of other dramatists as well.

Let me close with a renewed plea to historians to consider these issues and to help literary scholars explore how textual differences may correlate with broader patterns of social and cultural change in the Elizabethan and Jacobean periods. To what extent can we reliably use broader generalizations about "high" and "low" culture to "place" different versions of plays in chronological or social terms? And how can we refine these generalizations by making use of each other's methods and investigations? At present, each discipline appears content to use the other as a stable evidentiary base for its own conclusions. But if each discipline instead recognizes the constructed, provisional basis of the other, literary scholars and historians can work together to particularize and complicate our interpretations of the early modern era.

10. The early versions of Othello, which I have not examined, may constitute a prominent exception. 
By defining what has appeared to be the most "elevated" version of each text as the Shakespearean "original," editors have evaded several interesting and difficult questions. They have, for one thing, neatly sidestepped consideration of Shakespeare's own spectacular career of upward mobility as his company prospered and he himself rose from "man" to "gentleman." This increase in status may have caused him to distance himself from his origins and to identify gentry or aristocratic status increasingly with discrimination in taste and refinement of language as his career progressed. By defining Shakespeare as a fixed, reliable touchstone for cultural value, modern editors - and many others as well-have enlisted him as a firm ally and precursor in the social rituals by which those of us who like to think of ourselves as educated define the degree of our own elevation and taste. Through much of our century, to find the bad quartos valuable would have been to reveal one's incapacity for the graceful, courtly dance of civility and order that we have traditionally posited as synonymous with Shakespeare.

University of Texas 